\title{
A challenging paediatric pathological femur fracture in pyknodysostosis (osteopetrosis acro-osteolytica): lessons learnt
}

\author{
Hosam E Matar, Leroy A James
}

Department of Trauma \& Orthopaedics, Alder Hey Children's Hospital, Liverpool, Merseyside, UK

\section{Correspondence to} Hosam E Matar,

hematar@doctors.org.uk

Accepted 6 November 2014

CrossMark

To cite: Matar HE, James LA. BMJ Case Rep Published online: [please include Day Month Year] doi:10.1136/bcr-2014207730

\section{DESCRIPTION}

Pyknodysostosis, also known as osteopetrosis acro-osteolytica, is a rare autosomal-recessive bone dysplasia characterised by osteosclerosis and short stature. It involves mutations in the gene that encodes cathepsin $\mathrm{K}$, a lysosomal metalloproteinase highly expressed in osteoclasts and important for bone matrix degradation. ${ }^{1}$ Clinical features also include kyphoscoliosis and deformities of the chest; higharched palate leading to severe upper airway obstruction; ${ }^{2}$ and dysmorphic facial features. Radiographs demonstrate a generalised increase in bone density. Histological evaluation shows attenuated Haversian canal systems with decreased osteoblastic and osteoclastic activities. Serum chemistries are normal. ${ }^{3}$

We present a case of a 12-year-old girl who presented with a diaphyseal femur fracture following a fall off a trampoline. She is known to have pyknodysostosis (figure 1) with severe obstructive sleep apnoea with overnight continuous positive airway pressure support. This was an isolated closed injury with no neurovascular deficit. Non-operative management is seldom appropriate for such injuries as it involves an unacceptably high rate of complications due to long periods of immobilisation. While surgical fixation offers early mobilisation and weight-bearing, it proves challenging in conditions associated with forms of osteosclerosis due to dense brittle bone. ${ }^{3}$

We performed closed reduction and internal fixation using a submuscular plating technique
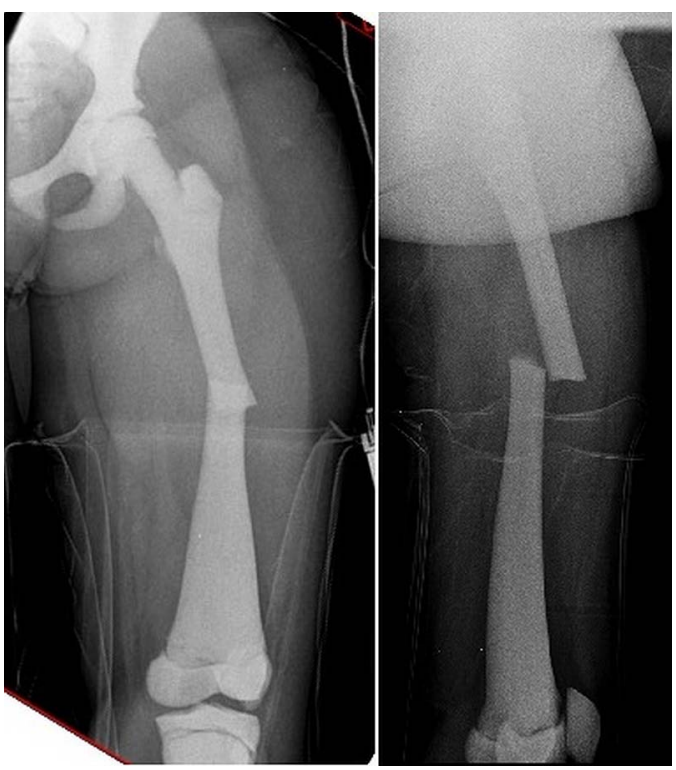

Figure 1 Anteroposterior and lateral radiographs of left femur with a disphyseal transverse fracture.
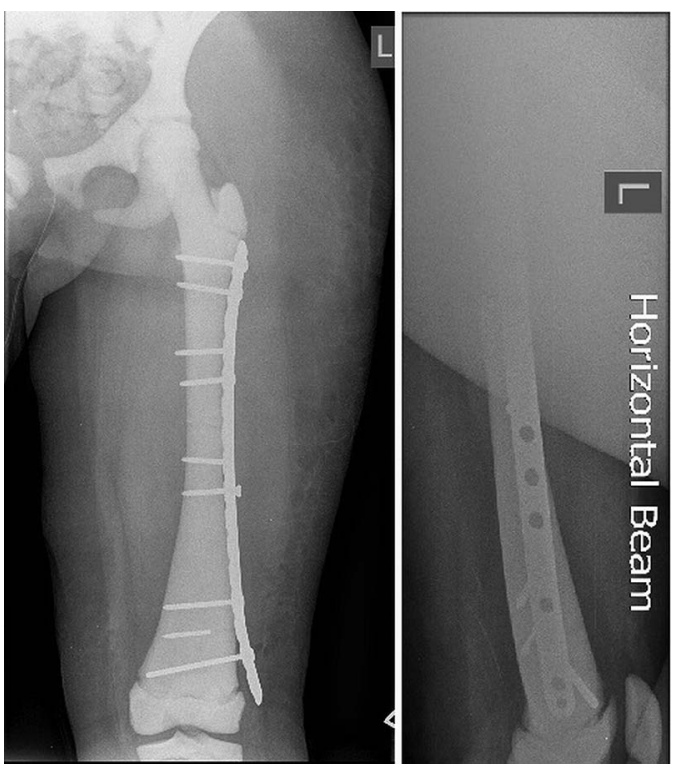

Figure 2 Anteroposterior and lateral radiographs of left femur following submuscular plate fixation.

(precontoured 16-hole $3.5 \mathrm{~mm}$ locking-plate) with uneventful recovery. Drilling for the screws proved most challenging; we did, however, overcome this by using one drill-bit per hole and constant irrigation with cold saline to reduce the effects of heat generated. Despite these precautions, iatrogenic breakage of drilling instruments is a likely complication (figure 2).

\section{Learning points}

- Formal preoperative anaesthetic assessment is essential as patients with pyknodysostosis often have an obtuse angle of the mandible, high-arched palate and upper airway obstruction.

- Preoperative surgical planning should include ensuring the availability of multiple drill-bits and being prepared for iatrogenic metalwork breakage.

- Intraoperatively, using one drill-bit per hole with constant cold saline irrigation is a useful technique. 
Provenance and peer review Not commissioned; externally peer reviewed.

\section{REFERENCES}

1 Arman A, Bereket A, Coker A, et al. Cathepsin K analysis in a pycnodysostosis cohort: demographic, genotypic and phenotypic features. Orphanet J Rare Dis 2014;26:60.
2 Kiran S, Goel M, Singhal P, et al. Pyknodysostosis: anaesthetic considerations-a case report. Internet J Anesthesiol 2009;21:13.

3 Arkader A, Dormans JP. Pathological fractures associated with tumours and unique conditions of the musculoskeletal system. In: Beaty JH, Kasser JK, eds. Rockwood and Wilkins' fractures in children. 7th edn. Philadelphia, PA: Lippincott, Williams \& Wilkins, 2010:120-91.

Copyright 2014 BMJ Publishing Group. All rights reserved. For permission to reuse any of this content visit http://group.bmj.com/group/rights-licensing/permissions.

BMJ Case Report Fellows may re-use this article for personal use and teaching without any further permission.

Become a Fellow of BMJ Case Reports today and you can:

- Submit as many cases as you like

- Enjoy fast sympathetic peer review and rapid publication of accepted articles

- Access all the published articles

- Re-use any of the published material for personal use and teaching without further permission

For information on Institutional Fellowships contact consortiasales@bmjgroup.com

Visit casereports.bmj.com for more articles like this and to become a Fellow 